\title{
Thomas Harriot on the coinage of England
}

\author{
Norman Biggs ${ }^{1}$ \\ Received: 12 April 2019 / Published online: 20 May 2019 \\ (c) The Author(s) 2019
}

\begin{abstract}
Thomas Harriot was the finest English mathematician before Isaac Newton, but his work on the coinage of his country is almost unknown, unlike Newton's. In the early 1600s Harriot studied several aspects of the gold and silver coins of his time. He investigated the ratio between the values of gold and silver, using data derived from the official weights of the coins; he used hydrostatic weighing to determine the composition of the coins; and he studied the methods used to calculate how metals should be combined in order to produce the required standard of purity. This work required not only arithmetical skill, but also great insight into the relationships between the various quantities, and here his 'greate invention of algebra' played its part. The gold and silver coins were critically important in the national economy at that time, because they had intrinsic value and represented the country's store of wealth. In his lifetime Harriot was supported by the patronage of Henry Percy, the Earl of Northumberland, who was a member of the Privy Council in 1604 when great changes to the English coinage were being made. After Harriot's death his papers remained under the control of one of his executors, Sir Thomas Aylesbury, who became Master of the Tower Mint in 1635. These facts suggest that his work on the coins was considered to be important for practical reasons, not just academic ones. In this article the interplay between the scholarly work and its application to matters of national significance will be analysed in depth. The conclusions also throw some light on the long-standing mystery surrounding the fate of Harriot's papers.
\end{abstract}

Mathematics Subject Classification 01A45 · 91-03

Communicated by Jeremy Gray.

Norman Biggs

nlbiggs@gmail.com

1 Department of Mathematics, London School of Economics, Houghton Street, London WC2A 2AE, UK 


\section{The gold-silver ratio}

A royal proclamation ${ }^{1}$ of 16 November 1604 declared that the values for the new coins of King James would be based on two rules:

one troy pound of crown gold $=744$ shillings;

one troy pound of sterling silver $=62$ shillings.

The weights of individual coins were also given in the proclamation, calculated according to the weight-value principle that the values of coins of a specific metal must be directly proportional to their weights. For example, a sterling silver coin with value one shilling should weigh 1/62 of a troy pound. The most noteworthy aspect of the proclamation was that the ratio of the values for crown gold and sterling silver was $744 / 62$, which is exactly 12 . This neat arrangement was clearly convenient, but it did not tell the whole story. The coinage metals, crown gold and sterling silver, were not the same as pure gold and pure silver, respectively, but only partly so. In fact, it was specified that crown gold should contain 11 parts in 12 of pure gold, and sterling silver should contain 37 parts in 40 of pure silver, by weight. In the international markets the ratio of the pure metals was important, because it determined whether profits could be made by arbitrage: that is, by exchanging English coins with those of another country where the ratio was different. ${ }^{2}$

Given that the declared ratio for the coined metals is 12 , one method of calculating the implied ratio for the pure metals is as follows. Since crown gold contains 11 parts of gold in 12, and sterling silver contains 37 parts of silver in 40, the figures for the pure metals are:

one troy pound of pure gold $=(12 / 11) \times 744$ shillings;

one troy pound of pure silver $=(40 / 37) \times 62$ shillings.

This gives the ratio

$$
\frac{(12 / 11) \times 744}{(40 / 37) \times 62}=\frac{666}{55}=12.109 \text { approximately } .
$$

The fact that the fineness of crown gold $(11 / 12=.916)$ is close to the fineness of sterling silver $(37 / 40=.925)$ has ensured that the 'true' ratio is close to the declared one. However, in the international bullion markets, the difference could be significant.

The calculation given above is not quite complete, because it ignores the value of the other parts of the coined metals, which were usually referred to as the alloy. The 3 parts in 40 of alloy in sterling silver were copper, which might well be regarded as of negligible value, but the 1 part in 12 of alloy in crown gold was supposed to be silver, and that surely should be accounted for. Intuitively, it seems that crown gold ought to be slightly less valuable (in comparison with sterling silver) than is suggested by the 12.109 figure.

Such calculations are necessarily arbitrary, because they depend on assumptions about how the values can be realised in practice. For example, there are additional costs when metals are exchanged, either at home or abroad, and when they are decomposed

\footnotetext{
${ }^{1}$ Larkin and Hughes (1973, item 47, 97-103).

2 The classic work on the significance of the ratio is Shaw (1895). For a more modern view, focussing on the Stuart period, see Supple (1959).
} 
into their constituent parts. However, there is a simple method of accounting for the silver in gold coins. ${ }^{3}$ It leads to the conclusion that the ratio 12.109 for the pure metals, based on the data given in the 1604 proclamation, should be decreased by $1 / 11$, which is 0.091 approximately, giving the result 12.018 .

King James's ministers certainly had access to arithmetical expertise at this time (Biggs 2019), but it is not clear that they realised that the adjusted ratio, 12.018, was so close to 12, the figure manifest in the proclamation. But there is clear evidence that Thomas Harriot was fully appreciative of the niceties of the situation, and we can now turn to his work on the subject.

\section{Harriot and his patrons}

For most of his life Thomas Harriot was supported by two famous patrons, Sir Walter Ralegh and Henry Percy, ninth Earl of Northumberland. In the 1580s Harriot had accompanied Ralegh on a voyage to North America, when he used his mathematical abilities to improve methods of navigation. His association with Ralegh continued, and he also became one of the scholars supported by Percy, who was the master of two great houses, Petworth in Sussex, and Syon near London. From about 1596 onwards Harriot lived in a comfortable house on the Syon estate, and in these fortunate circumstances he was able to devote almost all his time and energy to his scientific work, without the need to obtain financial support by publishing his results. But the patronage also had negative aspects: he would be affected when the slings and arrows of outrageous fortune were directed against his patrons, as indeed they were.

Over 8000 pages of his manuscript notes have survived, and much of this work was far ahead of its time. His biographer (Shirley 1983) describes the history of these manuscripts, but it is a story too complicated and too depressing to recall here. Only since 2011 has it become possible to make a comprehensive study of the papers, thanks to the publication of the entire archive under the auspices of the European Cultural History Online. ${ }^{4}$ We shall be concerned mainly with material in the eight bound volumes now residing in the British Library. ${ }^{5}$ For convenience, we shall refer to the pages of these volumes by symbols like $\mathbf{6 7 8 8 / 1 1 2 v}$, denoting folio $112 \mathrm{v}$ in volume 6788. Anyone attempting to use this material must be aware that the papers in the British Library volumes, as they were bound in 1811, are in a totally disordered state, and no inferences can be drawn from the location of any item within the set.

Ralegh's relationship with Queen Elizabeth had often been stormy, and the queen's death in March 1603 was soon followed by a charge of high treason against him. After a strange trial, during which the leading lawyers of the day presented unsubstantiated allegations as if they were established facts, Ralegh was found guilty and condemned to death. The sentence was suspended by King James, but Ralegh was confined in the

\footnotetext{
3 This is described in modern terms in 'Appendix 1'.

4 echo.mpiwg-berlin.mpg.de.

5 BL Add MS 6782-6789.
} 


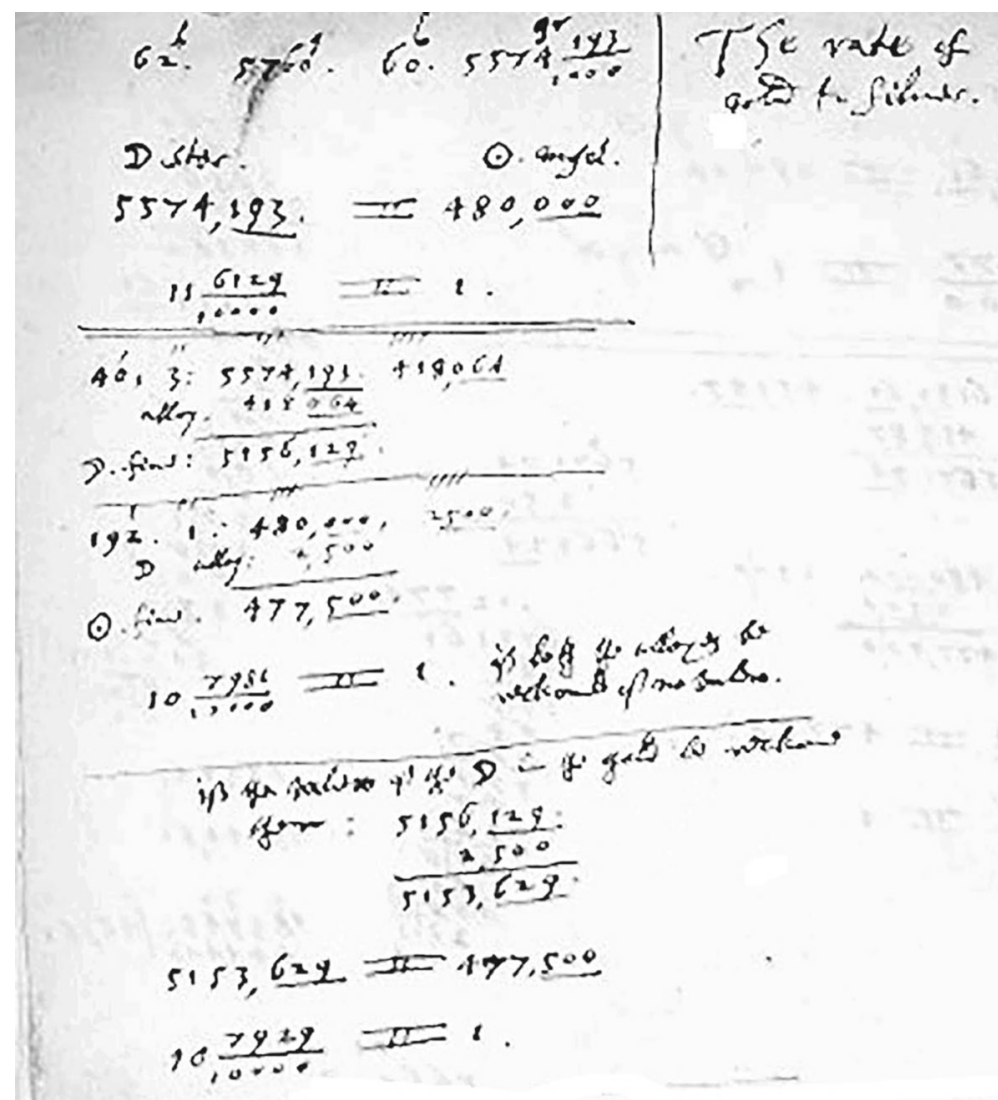

Fig. 1 Harriot's calculation of the ratio, using angel gold and sterling silver. CBritish Library Board BL Add MS 6788 f.112v

Tower of London at the king's pleasure. Harriot had helped with the preparation of Ralegh's defence, and this led to vitriolic denunciation of him by the prosecutors, on the grounds (among others) that he had encouraged Ralegh in atheistic beliefs (Shirley 1983, 303-317). This verbal assault, by some of the most powerful men in the land, seems to have had a devastating effect, because there is no evidence in Harriot's papers of any scientific work for about eight months after 18 September 1603.

The first sign of Harriot resuming his scientific work is found in three folios, all dated 25 July 1604. There he lists the results of some experiments on the density of salt solutions. Later that year he carried out many experiments on other substances, including gold and silver coins. The details will be discussed in Sect. 5, but we shall look first at his work on the gold-silver ratio. Although this is undated, it has some connections with the density experiments, and detailed analysis suggests that it may well pre-date them. 


\section{Harriot's calculations of the ratio}

Harriot's calculations followed the lines described in Sect. 1. He set out to find the ratio of pure metals, based on data about the fineness of the coins and their relative values. The context of his work was different from that of the officials who drafted the royal proclamations, and his methods were somewhat mysterious. We shall focus here on the context, which is of historical interest; the arithmetical methods will be analysed in detail in 'Appendix 2'.

The three relevant folios are $\mathbf{6 7 8 8 / 1 1 2 v}, \mathbf{6 7 8 8 / 1 1 2 r}$, and $\mathbf{6 7 8 6 / 4 5 5 r}$, which form an ordered set of related calculations. Part of the first one is shown in Fig. 1. Harriot's main concern was angel gold, a metal used in England for coins of gold since the thirteenth century. It contained only 1 part in 192 of alloy, in contrast to the crown gold discussed in Sect. 1, which was introduced in 1523, and contained 1 part in 12 of alloy. The name angel gold arose because the most common coin struck from this metal was the angel, valued at 10 shillings and struck at the rate of 72 to the troy pound of 5760 grains, so that each angel weighed exactly 80 grains. These figures had been used throughout most of Elizabeth's reign, but in 1601 an indenture to the Mint had decreed that 73 angels be struck from a troy pound, so the weight of an angel was slightly reduced. ${ }^{6}$ In fact, Harriot used the 80 grains figure, although his data for the sterling silver coins were the figures newly specified in the 1601 indenture, 62 shillings to the troy pound.

In 6788/112v the subject is an 'old' angel weighing 80 grains, with the traditional value of 10 shillings. This defines a coined metal with the property that 60 shillingsworth of it weighs 480 grains. Harriot calculates that 60 shillings-worth of the current sterling silver weighs

$$
(60 / 62) \times 5760=5574.193 \text { grains }
$$

and so the ratio for the coined metals is

$$
(5574.193) / 480=11.6129 .
$$

Harriot next obtains the ratio for the pure metals 'if both the alloys be reckoned as of no value', which gives the result 10.7981 . Finally, he does the calculation 'if the value of the [silver] in the gold be reckoned for', which leads to the ratio 10.7929. Note that the adjustment is 0.0052 , which is just $1 / 191$, the ratio of silver to gold in the angel gold. Harriot does not explain why this is so (he rarely explains anything). ${ }^{7}$

The calculation in $\mathbf{6 7 8 8 / 1 1 2} \mathrm{r}$ differs in that it is now assumed that an angel is valued at 11 shillings. Here the results are given with only two places of decimals, and the final adjustment is omitted, presumably as being too small to be significant in practice. The results are that the ratio of the coined metals is 12.77 , and the (unadjusted) implied ratio is 11.87 .

\footnotetext{
6 For details of the indenture see Challis (1992, 737).

7 The algebraic background is discussed in 'Appendix 2'.
} 
In 6786/455r Harriot assumes that an angel is worth 12 shillings. On this page there are many scrappy calculations, but apparently only one result: the implied ratio is $10656 / 955$, or about $111 / 6$.

The fact that there are three calculations, based on three different assumptions about the value of an angel coin, suggests some possible scenarios for this work. The intention may have been to estimate the true value of some old Elizabethan angels, both in England (based on the current sterling silver coins) and abroad (based on the implied ratio of gold to silver). Harriot himself had a small, but not insignificant, income, and almost certainly owned some gold coins. His patron, Henry Percy, the Earl of Northumberland, received a substantial income from his estates, and would have had a very personal interest in the value of the coins stored in his treasury.

Another motivation could have stemmed from Northumberland's position in the government. Henry Percy had assiduously cultivated the favour of James Stuart and, shortly after the latter was proclaimed king of England in 1603, he had been admitted to the Privy Council. James had already been king of Scotland for many years, and the systems of coinage in the two countries were quite different. With the aid of the Council, James set out to reconcile them, and surely Henry Percy would have been involved in discussions about the new coinage. This was a matter of the greatest importance (and some difficulty), because the coins of gold and silver represented the wealth of the nation at that time, and thus had a profound influence on all aspects of government. On 7 June 1603 the Privy Council examined the coins produced by the Mint at the traditional Trial of the Pyx, ${ }^{8}$ and Henry Percy may well have been present on that occasion. On the following day he received King James at Syon House, confirming his standing in the new administration (Shirley 1983, 301). These events may have had some bearing on Harriot's experiments, to be described in Sect. 5.

We know that the detailed calculations in preparation for the proclamation of November 1604 were seen by Robert Cecil, the king's chief minister, because there is a draft copy of the document with his corrections. ${ }^{9}$ It is also likely that the matter was considered very carefully by the officers of the Mint. In the event, the proclamation covered only the coins of crown gold and their relationship with the sterling silver. Little angel gold had been coined for some years past, but it was thought important to continue with it, for reasons of national prestige. However, it was not until July 1605 that the Mint was authorised to proceed with a new coinage of angels. The decision had been taken to maintain the traditional value of the angel at 10 shillings, but to reduce the weight, from the 1601 figure of 73 per troy pound to 81 per troy pound. The true ratio for the pure metals was thus 12.143, slightly greater than the figure of 12.018 implied by the coins of crown gold (Sect. 1). In fact very little angel gold was actually produced. ${ }^{10}$

The content of the three folios discussed here provides some clues as to their date. The fact that sterling silver is reckoned at 62 shillings per troy pound means that they must have been written after July 1601, when that standard was first introduced. But it is more difficult to specify a terminal date. It is almost certain that it was before July

\footnotetext{
8 The verdict of this trial has been published (Watson 1962, 102).

9 TNA SP $14 / 10 / 20$.

${ }^{10}$ For the annual output, see Challis $(1992,302)$.
} 
1605, when the weight and value of angel gold were officially fixed, and there is reason to think that it was before September 1604, when Harriot carried out experiments on the density of the coins, to be discussed in Sect. 5. In any case, the purpose seems to be clear: to establish the relative value of old Elizabethan angels, based on assumptions about their current price.

\section{The measurement of density in the late sixteenth century}

The bound volumes of Harriot's manuscripts contain many references to his experimental work on density. In connection with this work he collected results published by other scholars, and these notes provide a unique insight into the state of the art at that time. Harriot's main motivation came from two of his long-standing lines of research. One was the refraction of light. In 1601 he had already discovered the rule now known as Snell's Law, after the man who rediscovered it two decades later. This work has been studied in detail by modern historians; an excellent account is given by Goulding (2012). The second line of research was ballistics, where he had conducted many experiments on falling objects. His attempts to discover a relationship between the density of an object and its rate of descent have been carefully described by Schemmel (2008). However, his study of gold and silver coins could not have been directly inspired by questions of optics or ballistics, and clearly it had more mundane origins.

The density of a substance can be defined as the weight of a unit volume. ${ }^{11}$ Nowadays the unit of weight is the gram and the unit of volume is the cubic centimetre. These units have been chosen so that the weight of a cubic centimetre of water is one gram, and the density of water is therefore 1. Very few precise measurements of density had been carried out before Harriot began his experiments, and most of them had been done by the direct method, which involves preparing a known volume of the substance and then weighing it. Both these operations required great skill and precision, and the results were unreliable. ${ }^{12}$ The main feature of Harriot's experiments was the use of hydrostatic weighing, which had its origins in Archimedes' famous Eureka moment: the realisation that when an object is immersed in water it experiences a buoyancy, which can be equated to the weight of the water it displaces. This principle is not only a deep theoretical insight, it also provides a method of measuring the density of an object. If the weight in air is $W_{1}$ and the weight in water is $W_{2}$, then the buoyancy $W_{1}-W_{2}$ is the weight of a quantity of water equal in volume to the object. The ratio of $W_{1}$ to $W_{1}-W_{2}$ is thus a measure of the density of the object in comparison to water, often called its specific gravity.

One of Harriot's sources was the work of the Spanish scholar now usually referred to as Juan Bautista Villalpando. Harriot's notes on Villalpando are bound between his work on the gold-silver ratio (described in Sect. 3) and his experiments on the coins (described in Sect. 5), but the juxtaposition may be quite accidental. Villalpando had

11 The correct scientific term is now 'mass', rather than 'weight', but it is convenient to use the old terminology, as Harriot did.

12 A further complication was that the results were expressed in the system of units which then prevailed in the country where the experiments were done. 
written a massive tome on the supposed glories of Solomon's Temple, a topic which required him to estimate the size of the vast amounts of gold contained therein. His work was regularly cited in later books on the weights and measures of the ancients. ${ }^{13}$

Harriot's folio 6788/109v contains results on the densities of various substances. The heading is partly illegible, but the gist is clear.

Anno . 1603 . lib . [???]

Johannes Baptista Villalpandus Cordubensis

societate Jesu . $\quad$ tractatus de ponderibus [???]

lib.1. cap.5. pro. 16 .

pag.302.

The date 'Anno 1603' probably refers to an edition (Villalpando 1603/4) published in Rome. ${ }^{14}$ On page 302 of that edition the densities of gold and water appear as Auro 2775 and Aqua 148, exactly as listed by Harriot, and Villapando's table of ratios of relative densities corresponds exactly to the one given by Harriot. Harriot's folio 6788/110r is a verbatim transcript of page 301, and folio $\mathbf{6 7 8 8 / 1 1 1 r}$ contains an unrelated geometrical problem from page 262 of the same source.

There is no evidence that Villalpando used the method of hydrostatic weighing, but there are references to it elsewhere in Harriot's papers. Folio 6788/229r is headed

The experiments of François M. de Foix, le grande Archimede

de notre age et qui le premier a decouverte la

vraye proportion des metaux en poids et en volume

as Bodin ...

The source here is the Theatrum Naturae, Lib II, written by the philosopher Jean Bodin (1597). Page 260 of that work contains some figures that Harriot copied, such as the proportion by weight of gold to copper, 1551:729, and on page 261 there is a mention of 'Franciscus Fuxaus Candalo, Gallicus Archimedes'. However, Harriot remarks that many of the figures have been 'false printed' by Bodin, and quotes as evidence some results of Lazarus Ercker ${ }^{15}$ and 'Clavius'. The latter writer is identified in Harriot's next folio $\mathbf{6 7 8 8 / 2 3 0 r}$, which is headed

\section{De Ponderibus metallorum Baptista in [???] pag. 631}

There follows a list of weights 'In aere' and 'In aqua' for twelve metals, including iron, lead, silver, and gold of various kinds. The terminology confirms that the results were obtained by hydrostatic weighing. The author is Giambattista della Porta, an Italian polymath whose treatise Magiae Naturalis was first published in 1558 and was later expanded into twenty volumes. The edition of this work used by Harriot has not been identified, but a translation into English was published under the title Natural Magick in 1658, and precisely the same figures as those listed by Harriot can be found on page 384, together with identifications of the gold coins (Della Porta 1658). This folio also contains some results of 'Gastonius Dulconis sive Clavei', from his Apologia Chrysopoeia, thus identifying the 'Clavius' mentioned in the previous folio.

\footnotetext{
13 For example: Greaves (1647), Arbuthnot (1727), Hussey (1836).

14 The title page has the date MDCIIII, but Hussey $(1836,3)$ says that Villalpando's book 'came out in 1603 '.

15 The reference is to his manual of assaying (Ercker 1574).
} 
Fig. 2 Harriot's drawing of a hydrostatic balance. (British Library Board BL Add MS 6788 f. $233 \mathrm{r}$

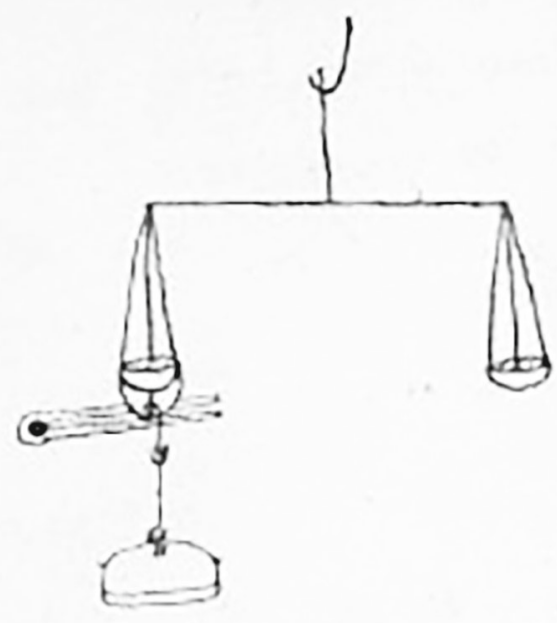

The last of this batch of folios is $\mathbf{6 7 8 8 / 2 3 1 r}$, which contains a sketch of an equalarm balance, clearly modified for weighing objects in air and in water (Fig. 2). This instrument closely resembles the hydrostatic balances of later times.

\section{Harriot's experiments on the density of gold and silver coins}

After the traumatic events of 1603, the first evidence of Harriot resuming his scientific work is found in three folios dated 25 July 1604, where he recorded the results of some experiments on solutions of salt (6788/245-247). Hydrostatic weighing was not used in those experiments, but shortly afterwards he used that method in some experiments on the density of gold and silver coins. His results are recorded in a series of folios 6788/108r, 107r, 105r, 106r, 104r, 103r, 102r. ${ }^{16}$ In these experiments Harriot takes the density of water as 1000; for example, the final result for the density of angel gold appears as $17829: 1000$. The results are worth examining in detail, as they illustrate the general method and notation used by Harriot. There are also some hints that Henry Percy, in his capacity as a member of the Privy Council, was taking an interest in this work.

Folio 6788/108r contains the results of three experiments on a parcel of 18 angel coins. The first experiment took place on 10 August 1604, and it was repeated (possibly, but not necessarily, with the same coins) on 10 September and 24 September. Figure 3 is a transcript of the results of the first experiment, in which the relative density of angel gold $(\odot)$ was found to be $17829: 1000$. The coins were first weighed in air ( $W_{1}=1408 \frac{1}{2}$ grains) and then in water $\left(W_{2}=1329 \frac{1}{2}\right.$ grains), using a set of weights

\footnotetext{
16 The folios are listed here in order of the first date written on them, but several of them have more than one date, because the same experiment was repeated.
} 


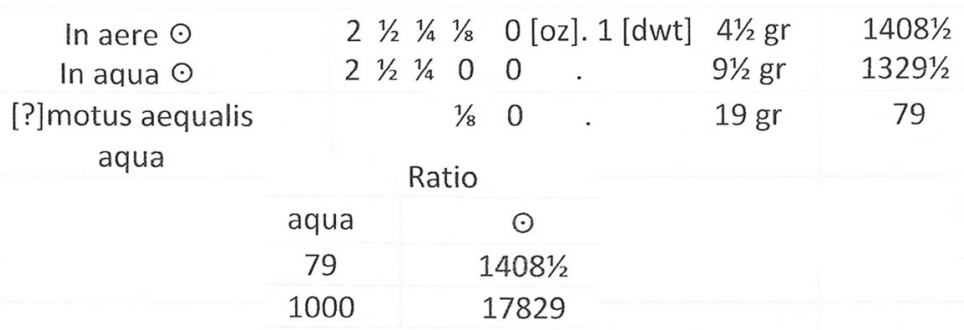

Fig. 3 Transcript of Harriot's experiment on the density of angel gold. CBritish Library Board BL Add MS 6788 f.108r

denominated in ounces, pennyweights, and grains. ${ }^{17}$ Since the difference $W_{1}-W_{2}$ was 79 grains, the relative density of angel gold was found to be $1048 \frac{1}{2}: 79$, which is equivalent to 17829 : 1000 in Harriot's standard form. This folio also contains the results obtained when the same experiment was repeated twice more, and the results of three similar experiments on tin.

Folio 6788/107r bears the date 18 August, with the month struck out and replaced by September. It contains the results of two experiments, one involving 100 silver shillings, and the other 118 gold angels. Presumably the angels consisted of a further 100 added to the 18 used on 10 August, a number that might have been obtained conveniently from Henry Percy's treasury. Harriot's first step on 18 August was to weigh the coins in air, and he notes, in passing, that the angels were underweight. The official mint weight of 118 angel coins at the old Elizabethan standard of 80 grains should have been 9440 grains, and at the slightly reduced 1601 standard, 9310 grains. In fact, these 118 coins weighed only 9220 grains. This fact did not affect the calculation of relative density, which came out as $19010: 1000$. When the experiment was repeated on 18 September, the weight in air was found to be $9308 \frac{1}{2}$ grains. This is significantly greater than the August figure, but very close to the 1601 indenture figure of 9310 grains. So it is possible that this batch was a new one, supplied by the Mint itself at Percy's request. In this case the relative density was found to be $19035: 1000$.

The next four folios in the series contain the results of other experiments of the same kind, and the fact that they are dated provides a clear framework for them. Folio 6788/105r bears the dates 26 August and 25 September. It records some experiments on mercury, leading to the conclusion that its relative density is about $13775: 1000$. Folio 6788/106r is dated 22 September and records more experiments on gold and sterling silver. The purpose is unclear, as no conclusions are stated explicitly. Folios 6788/104r and 6788/103r are dated 25 September and list the results of more experiments relating to 118 angels, 100 shillings, and mercury, as well as some new substances, copper, bismuth, tin, and glass.

The last folio in the series, $\mathbf{6 7 8 8} / \mathbf{1 0 2} r$ dated 26 September, has a different format, and its purpose is not immediately obvious. As usual, Harriot gives no explanation whatsoever, but the arithmetic suggests that he was trying to test whether his assump-

171 ounce $=20$ pennyweights, 1 pennyweight $=24$ grains . 


\begin{tabular}{|c|c|c|c|c|}
\hline & & $\begin{array}{c}\odot \\
191\end{array}$ & $\begin{array}{l}q \\
1\end{array}$ & $\begin{array}{l}\odot \text { fine } \\
19151\end{array}$ \\
\hline Angel gold in aere & 9229.9 & 9181.9 & 48.0 & \\
\hline Angel gold in aqua & 8745.1 & & & \\
\hline aqua & 484.8 & 479.4 & 5.4 & 1000 \\
\hline
\end{tabular}

Fig. 4 Transcript of Harriot's calculation regarding 118 angel coins. CBritish Library Board BL Add MS 6788 f. $102 \mathrm{r}$

tions about the composition of the coins were correct-and in doing so he made a significant discovery.

The background to this problem was the 'Trial of the Pyx', the procedure used to ensure that the Mint was producing gold and silver coins of the fineness specified by the indentures. These trials were held regularly, under the supervision of the Privy Council, and it is possible that Henry Percy attended the one held on 7 June 1603. The officers of the Mint were required to provide samples of the coins that they had made, and these were assayed in comparison with 'trial plates', which were presumed to be of the standard required by the indentures. Unfortunately the technology available at that time was not fit-for-purpose, and later analysis has shown that the trial plates were not accurate. For example, a trial plate of angel gold made in 1605 was significantly worse. $^{18}$

Whether or not Henry Percy had attended the trial in June 1603, he would have been aware of its importance, and he would have recognised the relevance of Harriot's methods. Harriot's folio $\mathbf{6 7 8 8 / 1 0 2 r}$ contains four calculations which appear to be checking whether the results of his hydrostatic experiments are consistent with the official standards of fineness.

The first calculation, for angel gold, is shown in Fig. 4. On the left are the weights of the 118 angel coins, in air, in water, and the difference, as recorded in folio $104 \mathrm{r}$ on the previous day. In the next column, headed $\odot$, there is the implied weight of the 191 parts of pure gold, 9181.9 grains, and the weight of the corresponding volume of water, 479.4 grains, calculated by taking the relative density of pure gold as $19151: 1000$. In the next column the figures for the one part of alloy are calculated by subtraction, thus: $9229.9-9181.9=48.0,484.8-479.4=5.4$. The conclusion is that the relative density of the alloy is $48.0: 5.4$.

In Harriot's standard form, the relative density is $8889: 1000$. The difficulty is that this is well below the density of silver: if the alloy is sterling silver, its density should be about $10370: 1000$, according to the results recorded in f.107r and f.104r. (If it is pure silver, it should be slightly greater.) Harriot's conclusion is revealed by the symbol he put at the head of the 'alloy' column, denoting copper, which he believed to have relative density $8795: 1000$, according to f.103r. Allowance must be

\footnotetext{
18 The official 191/192 figure for angel gold is equivalent to $99.48 \%$ pure gold. The 1605 trial plate is only $99.03 \%$ pure, although one made in 1560 is actually $99.43 \%$ pure (Watson 1962).
} 
made for slight inaccuracies in the figures used for the densities of the metals, as well as experimental errors, but the conclusion is clear: the alloy in Harriot's angels was mainly copper, rather than silver. This is contrary to his assumption in the calculations of the gold-silver ratio (Sect. 3), where the alloy was explicitly assumed to be silver. In fact, it appears that the composition of the alloy was never stipulated officially. The requirement was only that coined gold should contain a certain proportion of pure gold, the rest being left to the discretion of the mint officers. The coinage of angel gold came to an end in the 1600 s, and crown gold ( 22 carats) became the norm. Modern assays have shown that copper gradually replaced silver as the alloy; not only was it cheaper, it also produced a more durable coin. ${ }^{19}$

\section{Harriot's later life and legacy}

In the autumn of 1605 the problems of King James and his government once again impinged on Harriot and his patrons. A small group of disaffected persons conceived the idea that England would be a better place if the king and all his ministers were murdered. They planned to do this by exploding a large quantity of gunpowder while parliament was in session. The plan was foiled at the last moment, with the arrest of Guy Fawkes in the early hours of Tuesday, 5 November 1605, and it quickly emerged that one of the plotters was Thomas Percy, a distant relation of Henry Percy. Thomas had been employed by the earl on business in the north of England and, unfortunately, he had visited and dined with the earl at Syon House on the day before the plot was foiled. That was enough to suggest that the earl might have been involved, as was the fact that he was in the line of succession to the throne. Furthermore, he was believed to be sympathetic to the Catholic cause. Harriot too was under suspicion, because he had been present during Thomas Percy's visit. The earl was interrogated at length, but no evidence of his involvement in the gunpowder plot was ever found. ${ }^{20}$ Nevertheless, he was confined in the Tower of London, where he remained for the next 16 years. Harriot was also imprisoned in the Tower, but only temporarily. The king was particularly suspicious of mathematicians in general and Harriot in particular, because it was believed that mathematics could be used to 'cast horoscopes', thus predicting the king's death, a treasonable offence.

Harriot was unwell during his imprisonment, but he was eventually released and was able to resume his scientific work. His interests turned towards astronomy, where his expertise in optics was put to good use. One of his most significant achievements was to construct a telescope and use it to draw features that he observed on the surface of the moon. This was in July 1609, four months before Galileo's more famous observations.

Although Harriot's earlier work on hydrostatic weighing and the coinage remained obscure, it was not completely forgotten. Indeed, now that we have a better understanding of the details, it is possible to argue that, in the decades after his death in 1621, it became significant in the affairs of the nation. The story that will unfold involves

${ }^{19}$ For example, the 1707 trial plate for crown gold contains approximately $91.7 \%$ gold, $6.0 \%$ silver and $2.3 \%$ copper, whereas the figures for the 1829 plate are $91.5 \%, 3.8 \%$ and $4.7 \%$. The 1873 plate contains only gold and copper (Watson 1962).

20 The details are given by Shirley (1983, 336-345). 
five main characters: Nathaniel Torporley, William Lower, John Protheroe, Thomas Aylesbury, and Walter Warner. These people did not form a close-knit group, like the one based on the fiction of the 'wizard earl' and the 'three magi' that has been so well debunked by his biographer (Shirley 1983, 358-364). But they all knew Harriot well and they understood his work - at least, they partly understood some parts of it, and they recognised its importance.

The earliest evidence of Nathaniel Torporley's link with Harriot is a letter from Paris, probably written in the early 1590s. It refers to a meeting with François Viète, who was the leading exponent of symbolic algebra at that time. Harriot's papers contain many notes on Viète's work, some of them based on information supplied by Torporley. ${ }^{21}$ Torporley remained in contact with the Syon group, and there is a mysterious document preserved in the Harriot papers $(\mathbf{6 7 8 9 / 5 2 4 r})$ which appears to suggest that Henry Percy wanted Torporley to carry out some work in hydrostatics. The document is dated in 1608, which may indicate that Harriot had lost interest in the subject. Indeed, no evidence of relevant activity by him at this time has been found, although a manuscript written by Torporley has survived. ${ }^{22}$ For many years Torporley was rector of a small parish in Worcestershire, and his contacts with the Syon group during that period must have been limited, but he will play another part in our story later.

The second of the five characters, Sir William Lower, was the husband of Penelope Perrot, the daughter of Henry Percy's wife Dorothy by her previous marriage. ${ }^{23}$ This connection led to Lower becoming familiar with Harriot and his work, and he corresponded with him regularly from 1607 onwards. Lower's letters were mainly about astronomical observations, but a more personal message, written in 1610, chides Harriot about his reluctance to publish the results of his research. ${ }^{24}$ One of Lower's complaints refers to the hydrostatic experiments: 'So you taught me the curious way to observe weight in Water, and within a while after Ghetaldi comes out with it in print.' The work referred to is the Promotus Archimedes of Marino Ghetaldi (1603). In fact, on the evidence of Harriot's own notes (Sect. 4), neither Ghetaldi nor Harriot can claim priority for developing the hydrostatic method.

Lower was actively involved with Henry Percy's financial affairs in Wales, and when he died in 1615 that role was taken over by John Protheroe. He was a close neighbour of Lower's in Carmarthenshire, and he also had interests in astronomy, so he would have been aware of Harriot's discoveries. More significantly, he seems to have inherited Lower's enthusiasm for the publication of Harriot's work. It has also been suggested that either Lower or Protheroe was responsible for introducing Harriot to the fourth man who was to play a part in that project, Thomas Aylesbury. ${ }^{25}$

Certain it is that Thomas Aylesbury's role in the project was central. The earliest known record of his friendship with Harriot is a letter (6789/439r) dated 15 April 1611, in which he thanks Harriot for sending some spectacles for the Lord High

\footnotetext{
21 A full account of Harriot's notes on the work of Viète has been given by Stedall (2008).

22 BL Add MS 4458.

23 For the details, see Shirley (1983, 388-410).

24 This letter has been published in full Shirley $(1983,1)$.

25 But the evidence is slim: see Shirley $(1983,414)$ and Stedall $(2002,90)$.
} 
Admiral, who was at that time Aylesbury's superior in the king's service. The letter is written in a friendly style, which suggests that Harriot and Aylesbury were already well acquainted. Folio 6789/443r is another letter from Aylesbury to Harriot, written in a similarly informal style, and dated 19 January 1618/9.

Shortly before his death in 1621 Harriot wrote a will, under the terms of which Torporley, Protheroe, and Aylesbury were all to be involved in the fate of his papers, together with Walter Warner, who was keeper of Henry Percy's great library. Torporley was to be the 'Ouerseer of my Mathematicall writings'. He was charged with preparing them for publication, with the assistance of Warner and others if necessary, and under the supervision of Aylesbury and Protheroe, who were two of the executors. Harriot died soon after making the will, and the procedure he had laid down began well, with all the characters playing their assigned roles. In particular, as has been shown by the work of Jacqueline Stedall, ${ }^{26}$ Aylesbury took his role as executor and trustee of the papers very seriously. His first step was to prepare an inventory, which survives in the bound volumes (6789/448-450). Torporley was thus able to give up his church duties and begin work on the project, supported by a pension from Protheroe, which was continued by Protheroe's widow after his death in 1624 . The papers contained a draft 'Treatise on Equations' and, given Torporley's interest in algebra, it was natural for him to regard the preparation of this material as his first task. But progress towards publication was slow, and eventually Aylesbury lost patience. He discharged Torporley and entrusted the work to Walter Warner, who had been named in the will as a potential assistant. Warner was a well-respected scholar with wide scientific interests, but his grasp of the algebraic material was not good. Nevertheless, by 1631 Warner had prepared a selection of the papers for publication, and Aylesbury gave his approval. The book was published under the title Artis Analyticae Praxis (Harriot 1631).

\section{The mystery of the Convenient Truncke}

By the time the Praxis appeared in print, Aylesbury had become a power in the land. He had been installed as a Master of Requests in 1627, and raised to the peerage as a baronet. His upward trajectory continued when he was given control of the nation's coinage. In 1631 he was appointed as the sole 'maker of weights and balances for the king's moneys of gold', and in 1635 he became joint master of the Tower Mint in London. Until now his qualifications for these appointments have been open to question, but his familiarity with Harriot's papers, which we now know contained research on the gold and silver coins, may well be the key. This material would have been highly relevant to his work at the Mint.

Aylesbury's familiarity with Harriot's work on the coinage provides us with a new perspective on subsequent events. The inventory he had prepared after Harriot's death did not mention coinage or hydrostatic weighing specifically, although it is possible that the bundle listed in 6789/449r as 'Demonstrata Archimedea 1 b' contained papers on the weight of coins. ${ }^{27}$ More significant was the fact, under the terms of the will,

\footnotetext{
26 Stedall $(2002,97-100)$.

27 On the other hand, it may have been related to quite different areas of Archimedes' work.
} 
and following the death of Protheroe, Aylesbury was now in sole control of all Harriot's papers. Furthermore, as a member of the royal administration, he had become accustomed to the arbitrary exercise of power. He had asserted his authority over Harriot's papers by removing Torporley, and in his capacity as maker of the gold weights he quarrelled with John Reynolds, the chief mathematician at the Mint, and had him imprisoned in the Fleet (Biggs 2017). His authority was not to be challenged lightly.

Notwithstanding his flourishing career as a mandarin, Aylesbury seems to have had a genuine interest in mathematics, and he continued to support Warner's work on the Harriot papers. Warner also produced work on other subjects, some of them related to Aylesbury's position at the Mint. For example, the manuscript ${ }^{28}$ which contains ' $\mathrm{Mr}$ Warners Tract of the Commixture of Metals for the Mint' is bound with (and may be contemporary with) another tract of Warner's, on optics. ${ }^{29}$

The 'Commixture of Metals' was a matter of great importance at the Mint: it was the method used to produce coins of the prescribed standard of fineness from the metals received at the exchanges, the fineness of which varied. In mathematics, the problem was known as Alligation. Harriot himself had studied it, using some examples from L'arithmetique of Simon Stevin (1585); indeed, in what may have been the very first practical application of his own algebraic notation, he had investigated the theoretical basis of the rules. ${ }^{30}$ This work would have been available to Warner and may have been the origin of his tract.

There is some evidence that Warner's tract was put to good use. The key figure is Sir Charles Cavendish, who was acquainted with Sir Thomas Aylesbury, and active in the dissemination of scientific ideas. The Cavendish family owned large estates in Nottinghamshire, where the bailiff was Huntington Smithson, an educated man whose name appears in the records of the Harleian collection as the transcriber of Warner's tracts. ${ }^{31}$ The Cavendish connection suggests that copying Warner's work was not simply an academic project. In 1642 William Cavendish, the elder brother of Sir Charles, was appointed commander-in-chief of the king's forces in the North and authorised to produce coins at the royalist mint at York, a project which would have required expertise in the 'Commixture of Metals' (Biggs 2018).

After Warner's death in 1643 the fate of his papers was a matter of some concern, but happily some of them survived. ${ }^{32}$ The work on coinage matters was mentioned by Samuel Hartlib in 1650, and some relevant papers were listed in a letter from John Collins to James Gregory written in 1668. In recent times a collection of Warner's papers has been discovered in the Northampton Record Office, where they await careful study

It is likely that Aylesbury recognised Warner's limitations as a mathematician, and that may be why he turned to a younger man. Dr John Pell was then famous as the rising

\footnotetext{
28 BL Harleian MS 6755.

29 BL Harleian MS 6756, dated 16 February 1634 (probably Old Style).

30 For details, see 'Appendix 3'.

31 See the notes on manuscripts 6755 and 6756 in volume 3 of A Catalogue of the Harleian Manuscripts in the British Museum (London 1808).

32 The details are given by Stedall (2002, 113-116).
} 
star of English mathematics, although his claim to fame was never quite clear. ${ }^{33}$ For his part, Pell was looking for someone who could support him in the style that Henry Percy had supported Harriot, and he must have seen Aylesbury as a potential patron. There are several records of his association with Aylesbury, including a verbatim account of a conversation in 1638 about Harriot's algebraic solution of a quadratic equation by completing the square. ${ }^{34}$ But, for whatever reason, Pell did not assist with the publication of Harriot's papers, and all too soon the troubles of the nation intervened once again.

In 1642 the rift between Parliament and King Charles escalated into civil war. The Tower Mint was taken over by parliamentary forces in August 1642, and Aylesbury moved to the royalist stronghold at Oxford, where he continued to serve as Master of Requests. Walter Warner died soon afterwards, and work on the Harriot papers must have ceased. There is, however, a mysterious document relating to Aylesbury's mint activities which appears to date from this period. James Ussher, Archbishop of Armagh, was in Oxford around this time, and among the papers in his extensive library there is one headed ${ }^{35}$

Sr Tho Ailesbury The fineness of silver at ye pound weight being given by Assaie, to finde out the rateable fineness of everie ounce $\&$ dwt thereof.

There is no clue as to why the Archbishop would have required this information. The document contains the results of some simple calculations, based on the rules of proportion, together with tables for valuing angel gold. The fact that angel gold was no longer being used for coinage only serves to deepen the mystery.

Although it is clear that Aylesbury retained his control over Harriot's papers, we have no firm evidence as to their whereabouts. It seems likely that Walter Warner had worked on them at one of Northumberland's houses, Syon and Petworth, which would have been more secure than Aylesbury's houses in London and Windsor, even before the outbreak of the Civil War. Surely Aylesbury would not have taken all the papers to Oxford, but he may have kept some of them. After the execution of the king in 1649 he went into exile in Antwerp, where Sir Charles Cavendish was also residing. Cavendish corresponded regularly with John Pell about mathematical matters, and in 1651 he wrote as follows: ${ }^{36}$

Sr Th: Alesburie remembers him to you \& desires to know if you would be pleased to show him the vse of Mr Hariots doctrine of triangulare numbers; which if you will doe he will send you the originall; I confess I was so farr in love with it that I copied it out.

The use of the word 'originall' is significant. Did Aylesbury also retain other 'originall' papers, perhaps ones more relevant to his official duties?

Aylesbury died in Breda in 1657 and the whereabouts of Harriot's papers remained a mystery for many years, in spite of several attempts to locate them. ${ }^{37}$ Harriot's

\footnotetext{
33 He remains famous today, because of 'Pell's equation', but the name is a mistake.

34 (Malcolm and Stedall 2005, 64, 79-85, 273-275).

35 TCD MS 797 folios 59r, 60v, 60r, 61v, 61r.

36 (Malcolm and Stedall 2005, Letter 114, 584).

37 Shirley (1983, 7-9).
} 
will $^{38}$ had decreed that, after work on the papers had finished, the executors should put them 'in a Convenient Truncke with a locke \& key [. . . to be placed in my Lord of Northumberlandes Library [. . . ]'. In 1784 a large collection of Harriot's papers was indeed found at Petworth House in Sussex, the stately home of the Percy family. So it seems that Aylesbury had correctly played his part in the execution of the will, although how that happened, when that happened, and whether all the papers were present, remains unclear. The Civil War, the Interregnum, and the Restoration may well have played their part in the story. Thomas Aylesbury was a royalist, and a steady one, but Algernon Percy, now master of Petworth, was a parliamentarian, and by no means steady. He had taken no interest in the Harriot project, and the fate of the papers was unlikely to concern him. When the papers were eventually unearthed at Petworth, the evidence was severely trampled by incompetent attempts to edit and conserve the material, which resulted in its disorder and dispersal. Only since the online publication of the surviving material in 2011 has it been possible to undertake a serious analysis of what Harriot actually wrote.

\section{Conclusion}

This article has explored the suggestion that some of Harriot's scientific and mathematical work was motivated by matters of national importance. The evidence comes partly from the circumstances of his patronage, and partly from the chronology. His patron, Henry Percy, was a rich man who had a very personal interest in financial affairs. He was also a member of the Privy Council at a time when a major reform of the coinage was being planned. Percy would surely have sought the advice of Harriot on technical matters like the gold-silver ratio, and both the details and the timing of Harriot's work lend support to this interpretation.

Many questions remain. The papers now published online may yet yield more clues, because their chaotic state provides hiding places for documents that might be relevant. Other contemporary sources may also provide new insights, if reviewed in the light of the evidence presented here.

Acknowledgements I am very happy to acknowledge my great debt to the creators of the Harriot online project at ECHO (European Cultural History Online). In addition to her work for that project, the writings of the late Jacqueline Stedall provided a great deal of pertinent information. I am grateful to Colin Allsbury for details of the Aylesbury material in the Ussher papers.

Open Access This article is distributed under the terms of the Creative Commons Attribution 4.0 International License (http://creativecommons.org/licenses/by/4.0/), which permits unrestricted use, distribution, and reproduction in any medium, provided you give appropriate credit to the original author(s) and the source, provide a link to the Creative Commons license, and indicate if changes were made.

\footnotetext{
38 Like the papers, the will was lost for many years, but it was eventually found towards the end of the nineteenth century. A transcript of the relevant section is available (Shirley 1983, 2, 29).
} 


\section{Appendices: Harriot's use of symbolic algebra}

By the end of the sixteenth century Algebra had been evolving over many centuries. Thomas Harriot's 'greate invention' was the symbolic notation that is now universal. There are many examples scattered throughout his manuscripts, some of them used to solve problems that are purely algebraic, such as the solution of quadratic and cubic equations. But he also applied his methods to illuminate subjects of a more mundane kind, such as the financial problems discussed in this article.

In some cases, such as his study of Alligation, the algebraic symbolism is explicit in the surviving manuscripts. In others, we can only infer from the arithmetical calculations that algebraic rules were used. Harriot may have made rough notes to guide his calculations; but, even if there were no notes, it is clear that his thinking was guided by rules that were essentially algebraic in form. In these appendices we shall use modern algebraic notation (which is very similar to Harriot's) to elucidate his methods.

\section{Appendix 1: The implied ratio and its adjustment}

For any metal $M$, denote the value of an amount of $M$ that weighs $x$ by $V_{M}(x)$. In arithmetical calculations the units of value and weight must be specified, but the principles can be understood without them. The weight-value relationship implies that the value of $x$ units is $x$ times the value of one unit, so $V_{M}(x)=x V_{M}(1)$. Denoting the constant $V_{M}(1)$ by $v_{M}$, we have the formula $V_{M}(x)=x v_{M}$. Consequently, for two metals $M$ and $N$, and any given weight $x$, the fraction $V_{M}(x) / V_{N}(x)$ is just $v_{M} / v_{N}$. This is the ratio for $M$ and $N$, and will be denoted here by $r(M, N)$.

We consider two metals, coined gold $c G$ and coined silver $c S$. The fineness of both metals is given, as is the declared ratio $r(c G, c S)=v_{c G} / v_{c S}$. Our aim is to obtain an expression for the implied ratio $r(G, S)$ of the pure metals, based on these data.

Suppose that one weight-unit of coined gold contains proportions $a$ of gold and $1-a$ of silver, and one weight-unit of coined silver contains proportions $b$ of silver and $1-b$ of a cheap metal $C$. Here $a$ and $b$ are numbers between 0 and 1 . It follows that

$$
v_{c G}=a v_{G}+(1-a) v_{S}, \quad v_{c S}=b v_{S}+(1-b) v_{C} .
$$

The term $(1-a) v_{S}$ is significant, because silver is a valuable metal, but the term $(1-b) v_{C}$ is conventionally ignored, because $C$ is cheap.

Let $r$ denote the declared ratio $r(c G, c S)$. Since $v_{c G}=r v_{c S}$, it follows from the two equations displayed above that

$$
a v_{G}+(1-a) v_{S}=r b v_{S}
$$

Dividing by $a v_{S}$ and rearranging, we have

$$
v_{G} / v_{S}=r(b / a)-(1-a) / a .
$$


Hence, the implied ratio for the pure metals, if the silver in coined gold is taken into account, is

$$
r^{* *}=r^{*}-(1-a) / a
$$

where $r^{*}=r(b / a)$ is the ratio if it is ignored. Note that the final adjustment, $(1-a) / a$, depends only on the fineness of the coined gold, not the coined silver. For crown gold $(a=11 / 12)$ it is $1 / 11$, and for angel gold $(a=191 / 192)$ it is $1 / 191$.

\section{Appendix 2: Harriot's method of accounting for the alloy}

Harriot's approach to the problem was different from the one described in the previous section, and no explanation of it has been found in his papers. The present writer was initially mystified, and was only convinced of its correctness after comparing the method with the formula for $r^{* *}$ displayed above.

Harriot based his calculations on the weight of an amount of metal $M$ having a given value $y$, which we shall denote here by $W_{M}(y)$. The relationship between Harriot's $W_{M}$ and the $V_{M}$ employed in Sect. 1 is simple. When $M$ is such that an amount with value $y$ has weight $x$, Harriot would say that $W_{M}(y)=x$, while our statement is $V_{M}(x)=y$. So we have what mathematicians now call a pair of inverse functions. We saw that the weight-value principle implies that $V_{M}(x)=x v_{M}$, from which it follows that $W_{M}(y)=y w_{M}$, where $w_{M}=1 / v_{M}$. The corresponding formula for the ratio $r(M, N)$, as used by Harriot, also follows: $r(M, N)=w_{N} / w_{M}$. The fact that the formula is 'upside-down' is really just common sense.

In his calculations (folio $\mathbf{6 7 8 8 / 1 1 2 v}$ ) Harriot takes the unit of value to be 60 shillings, and the unit of weight to be one grain (one troy pound $=5760$ grains). He is concerned with coined gold $c G$ in the form of angels, 191/192 parts fine, with the 'old' value of 10 shillings for a coin weighing 80 grains. Thus, the weight of 60 shillings-worth is 480 grains. The coined silver $c S$ is sterling silver, 37/40 fine, with its post-1601 value of 62 shillings for a troy pound. Hence, the weight of 60 shillings-worth is $(60 / 62) \times 5760=5574.193$ grains. In the notation defined above,

$$
w_{c G}=480, \quad w_{c S}=5574.193
$$

Harriot's first calculation is the ratio $r=r(c G, c S)$ for the coined metals:

$$
r=\frac{w_{c S}}{w_{c G}}=\frac{5574.193}{480}=11.6129
$$

Next he calculates the implied ratio for the pure metals, with the assumption that 'both the alloys be deemed of no value':

$$
r^{*}=\frac{(37 / 40) \times 5574.193}{(191 / 192) \times 480}=\frac{5156.129}{477.5}=10.7981 .
$$


The multipliers $37 / 40$ and $191 / 192$ are the finenesses $b$ and $a$, respectively, so 5156.129 grains is the weight of pure silver in 60 shillings-worth of sterling silver, and 477.5 grains is the weight of pure gold in angel gold of the same value. In algebraic terms the formula is

$$
r^{*}=\frac{b w_{c S}}{a w_{c G}}=r(b / a),
$$

so this is clearly just another way of expressing the relationship obtained in the previous section.

Finally, he considers what happens when the value of the silver in the gold is taken into account. His calculation is:

$$
r^{* *}=\frac{5156.129-2.500}{477.5}=10.7924
$$

As usual, he gives no explanation. At first sight it is not obvious why, by subtracting the 2.500 grains of silver in the angel gold from the 5156.129 grains in the sterling silver, the correct result has been has been obtained. However, in algebraic terms his formula is

$$
r^{* *}=\frac{b w_{c S}-(1-a) w_{c G}}{a w_{c G}},
$$

which is equivalent to the formula displayed at the end of the previous section. Given Harriot's great insight into matters mathematical, we must credit him with a mental picture of the situation which made it obvious (to him).

\section{Appendix 3: Harriot on Alligation}

Harriot's work on Alligation can be found in 6783/312r, 313v. The first of these folios contains notes on Stevin's L'arithmetique (1585), specifically the third part of that work, La Practique d'arithmetique, pages 45-47. ${ }^{39}$ In order to explain the underlying problem, we can do no better than use the notation that appears in Harriot's next folio, 313v, entitled 'Of Alligation' (Fig. 5).

The basic problem is to produce an amount $q$ of standard gold, with fineness $c$ carats, given that two sorts of non-standard gold are available. One sort has fineness $b$ carats and is worse than the standard, and the other has fineness $d$ carats and is better. The solution is to combine $d-c$ parts (by weight) of the worse sort with $c-b$ parts of the better sort. This rule is easily verified in algebraic terms. The mixture will weigh $w=(d-c)+(c-b)$ units in all, and its fineness will be $f$ carats, where

$$
w f=(d-c) b+(c-b) d
$$

39 An English translation is available at www.dnc.knaw.nl. 


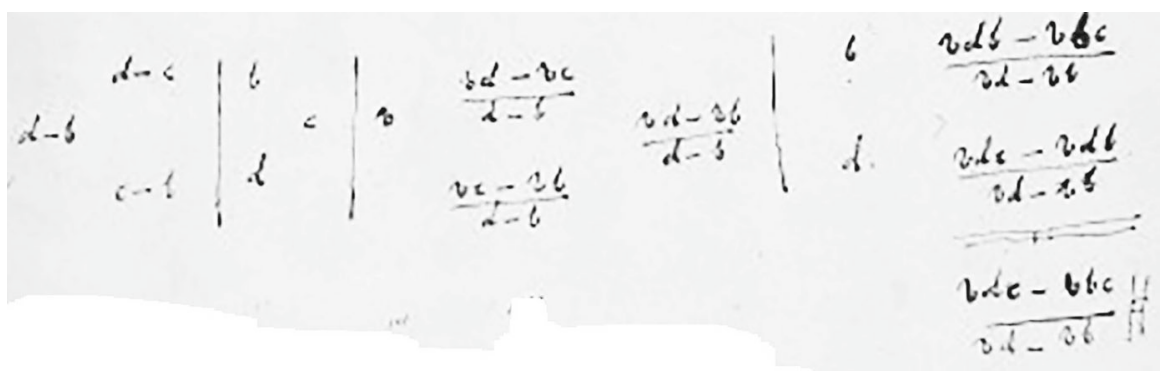

Fig. 5 Harriot's algebraic treatment of Alligation. OBritish Library Board BL Add MS 6783 f.313v

Elementary algebra tells us that

$$
w=(d-c)+(c-b)=d-b \text { and }(d-c) b+(c-b) d=(d-b) c=w c,
$$

so $f=c$, as required. Although we now call this argument 'elementary', it must be stressed that, at the time Harriot wrote his notes, the use of algebra for this purpose was entirely original.

Stevin had given an example of the basic problem, and the following example of the more general problem where more than two sorts of gold are available.

\section{EXEMPLE III}

Un maistre de monnaies à cinq sortes d'or, la premiere de 2 Karats, la seconde de 3 Karats, la troisiesme de 4, la quatriesme de 11, la cinquiesme de 12; et veut masse de 20 marcqs à 5 Karats. Combien se prendre de l'or de chacune sorte?

Stevin's solution is to combine the sorts in pairs so that each combination has the required fineness. Since the mixtures produced by the pairings all have the right fineness, they can be combined in any way to produce the total amount required. Indeed, as Stevin points out, whenever more than two sorts are available there are infinitely many solutions to the general problem. In his example there are three sorts $(2,3,4$ carats) that are worse than the required standard (5 carats), and two sorts (11, 12 carats) that are better, so there are six possible pairs. For reasons that he does not explain, Stevin chooses to use just three of them. Applying the simple rule for combining a worse sort ( $b$ carats) and a better sort ( $d$ carats), he works out the amounts needed in these cases, given that the required standard is $c=5$.

For the pair $b=2$ and $d=11$ use the proportions $d-c=6$ and $c-b=3$.

For the pair $b=3$ and $d=12$ use the proportions $d-c=7$ and $c-b=2$.

For the pair $b=4$ and $d=11$ use the proportions $d-c=6$ and $c-b=1$.

So the rule for the first pair is to combine 6 parts of 2-carat gold and 3 parts of 11-carat gold. Applying the same rule to the other pairs, and putting the mixtures together, it follows that a solution is obtained by combining 6 parts of 2-carat gold, 7 parts of 3-carat gold, 6 parts of 4-carat gold, $3+1=4$ parts of 11-carat gold, and 2 parts of 12-carat gold. This produces a total of 25 parts of metal of the required fineness. The required amount is actually 20 marks, which must be divided in the proportions $6: 7: 6: 4: 2$. Specifically, the amount of 2 -carat gold required is $(6 / 25) \times 20=4 \frac{4}{5}$ marks, and so on. 
Harriot made a note of Stevin's solution in 6783/312r, together with other jottings of the same kind. In the next folio (Fig. 5) he set out the rule for pairing in algebraic terms, including the determination of the actual quantities required in terms of the total amount $q$.

\section{Appendix 4: Analysis of mixtures by the hydrostatic method}

One of Harriot's significant innovations was his application of the hydrostatic method to the analysis of coined gold (Fig. 4). We recall that, in ancient times, irregular lumps of gold or silver were often used as money. Because it was difficult to determine accurately the volume of such objects, they were usually measured by weighing them. The same was true for coined money, since the weight of a coin could be controlled much more effectively than its shape and thickness. One consequence of this fact was that mixtures of metals were (and still are) described in terms of the proportions of the constituents by weight. Another consequence was the inaccuracy of direct measurements of density (because both weight and volume had to be measured).

An alternative method of measuring density, which requires weighing only, goes back to Archimedes. The method is explained in Sect. 4 of the main article, together with evidence suggesting that it was not until the end of the sixteenth century that the hydrostatic method was taken seriously.

In general, the application of hydrostatic weighing to the assay of mixtures can be described as follows. A mixture is formed by combining $n$ substances in proportions $p_{1}, p_{2}, \ldots, p_{n}$, where $p_{i}(1 \leq i \leq n)$ is a number between 0 and 1 . The substances have densities $d_{1}, d_{2}, \ldots, d_{n}$, and the mixture has density $D$. It follows that one weightunit of the mixture has volume $1 / D$, and $p_{i}$ weight-units of substance $i$ have volume $p_{i} / D_{i}$. Thus

$$
\frac{1}{D}=\frac{p_{1}}{d_{1}}+\frac{p_{2}}{d_{2}}+\cdots+\frac{p_{n}}{d_{n}} \text { where } p_{1}+p_{2}+\cdots+p_{n}=1
$$

The application of this formula depends on the circumstances. Suppose the mixture is composed of just two substances, and their densities $d_{1}, d_{2}$ are known (from a table, say). Then an experimental determination of the density of the mixture $D$ gives the proportions, by solving the equations

$$
\frac{p_{1}}{d_{1}}+\frac{p_{2}}{d_{2}}=\frac{1}{D}, \quad p_{1}+p_{2}=1
$$

This is the situation if coined gold is actually composed of gold and silver only. But if there are three components, gold, silver, and copper, then we have only two equations for three unknowns, and the proportions cannot be found. However, with coined gold, the proportion of pure gold was allegedly fixed, so the proportions of silver and copper can be calculated. The calculation shown in Fig. 4 was Harriot's attempt to test his experimental results against the official prescriptions. 


\section{References}

Arbuthnot, J. 1727. Tables of ancient coins, weights and measures. London: J. Tonson.

Biggs, N. 2017. Mathematics at the mint: A seventeenth-century saga. British Numismatic Journal 87: $151-161$.

Biggs, N. 2018. Without grains: Weighing silver coins in the civil war. British Numismatic Journal 88: 77-87.

Biggs, N. 2019. John Reynolds of the mint: A mathematician in the service of king and commonwealth. Historia Mathematica, published online December 2018.

Bodin, J. 1597. Universae Theatrum Naturae Lib. II. Lugduni: Roussin.

Challis, C. 1992. A new history of the royal mint. Cambridge: University Press.

Della Porta, G. (tr. R. Gaywood). 1658. Natural magick in XX books. London: Thomas Young and Samuel Speed.

Ercker, L. 1574. Beschreibung allerfurnemisten mineralischen Ertzt. Prague: Georg Scwartz.

Ghetaldi, M. 1603. Promotus Archimedes. Rome: A Zannettum.

Goulding, R. 2012. Chymicum in morem: Refraction, matter theory, and secrecy in the Harriot-Kepler correspondence. In Thomas Harriot and his World, ed. Robert Fox. Farnham: Ashgate.

Greaves, J. 1647. A discourse on the Roman foot and denarius. London: W. Lee.

Harriot, T. 1631. Artis analyticae praxis. London: Barker.

Hussey, R. 1836. An essay on the ancient weights and measures. Oxford: University Press.

Larkin, J.F., and P.L. Hughes. 1973. Stuart royal proclamations, vol. 1. Oxford: University Press.

Malcolm, N., and J. Stedall. 2005. John Pell (1611-1685) and his correspondence with Sir Charles Cavendish. Oxford: University Press.

Schemmel, M. 2008. The English Galileo: Thomas Harriot's work on motion as an example of pre-classical mechanics. Dordrecht: Springer.

Shaw, W. 1895. The history of currency 1252-1894. London: Wilson and Milne.

Shirley, J. 1983. Thomas Harriot: a biography. Oxford: Clarendon Press.

Stedall, J. 2002. A discourse concerning Algebra. Oxford: University Press.

Stedall, J. 2008. Notes made by Thomas Harriot on the treatises of François Viète. Archive for the History of the Exact Sciences 62 (2): 179-200.

Supple, B. 1959. Commercial crisis and change in England 1600-1642. Cambridge: University Press.

Villalpando, J.B. 1603/4. In Ezekiel explanationes Tome III Apparatus Urbis ac Templi. Rome: Ciaconii.

Watson, J.H. 1962. Ancient trial plates. London: HMSO.

Publisher's Note Springer Nature remains neutral with regard to jurisdictional claims in published maps and institutional affiliations. 